\title{
Penerapan metode pembelajaran penemuan terbimbing untuk meningkatkan pemahaman konsep kubus dan balok siswa kelas VIII-4 SMP Negeri 23 Malang
}

\author{
Rahayu Setyawati, Dwiyana* \\ Universitas Negeri Malang, Jl. Semarang No. 5 Malang, Jawa Timur, Indonesia \\ *Penulis korespondensi, Surel: dwiyana.fmipa@um.ac.id
}

Paper received: 01-09-2021; revised: 15-09-2021; accepted: 30-08-2021

\begin{abstract}
based on the results of interviews and observations in class VIII-4 of SMP Negeri 23 Malang showed students difficulties in understanding mathematical material, one of them is material related to geometry, namely cubes and beams. Pre-action test results show that students' conceptual understanding is still low. One of the factors causing low understanding of students concepts is the learning process is still teacher-centered. In Research, researchers refined the teaching process by applying guided discovery learning methods to cube and beam material. This study aims to describe the process of applying guided discovery learning methods that can improve the understanding of the concept of cubes and beams. This type of research is Classroom Action Research (CAR) conducted in two cycles. Based on the results of the study showed that the understanding of students' concepts increased with the percentage of completeness of the final test of the first cycle was 66.67percent and experienced an increase in the second cycle with a percentage of completeness of 86.6 percent.
\end{abstract}

Keywords: guided discovery; concept Understanding

\begin{abstract}
Abstrak
Berdasarkan hasil wawancara dan observasi di kelas VIII-4 SMP Negeri 23 Malang menujukkan siswa kesulitan dalam memahami materi matematika salah satunya materi yang berkaitan dengan geometri yaitu kubus dan balok. Hasil tes Pratindakan menujukkan pemahaman konsep siswa masih rendah. Salah satu faktor penyebab rendahnya pemahaman konsep siswa adalah proses pembelajaran masih berpusat pada guru. Pada Penelitian, peneliti memperbaiki proses mengajar dengan menerapkan metode pembelajaran penemuan terbimbing pada materi kubus dan balok. Penelitian ini bertujuan untuk mendeskripsikan proses penerapan metode pembelajaran penemuan terbimbing yang dapat meningkatkan pemahaman konsep kubus dan balok. Jenis penelitian ini adalah Penelitian Tindakan Kelas (PTK) yang dilaksanakan dalam dua siklus. Berdasarkan hasil penelitian menujukkan bahwa pemahaman konsep siswa meningkat dengan persentase ketuntasan tes akhir siklus 1 adalah 66,67 persen dan mengalami peningkatan pada siklus 2 dengan persentase ketuntasan 86,6 persen.
\end{abstract}

Kata kunci: penemuan terbimbing; pemahaman konsep

\section{Pendahuluan}

Matematika merupakan mata pelajaran yang diajarkan dalam semua jenjang mulai sekolah dasar hingga perguruan tinggi. Matematika merupakan ilmu pengetahuan yang memiliki karakteristik khusus yaitu memiliki objek kajian yang abstrak, bertumpu pada kesepakatan, berpola pikir deduktif, memiliki simbol yang kosong dari arti, memperhatikan semesta pembicaraan, konsisten dalam sistemnya (Subanji, 2013). Salah satu tujuan mata pelajaran matematika adalah memahami konsep matematika (Permendikbud no 58 tahun 2014). Konsep merupakan materi pembelajaran dari suatu objek yang bersifat abstrak atau konkret dalam bentuk definisi atau pengertian (Trianto dalam Banowati, 2015). Menurut 
National Council of Teacher of Mathematics (NCTM) (dalam Alfiah, 2016) menyatakan bahwa "Learning mathematics with understanding is essential" yang berarti pembelajaran matematika dengan pemahaman adalah yang utama.

Menurut Akmil (2012), pemahaman konsep merupakan kemampuan memahami, memaknai, mengidentifikasi, dan mampu menjelaskan kembali konsep dengan rinci. Dalam belajar matematika, pemahaman konsep penting bagi siswa karena konsep dalam matematika saling berkaitan dengan konsep lainnya. Menurut Rusenffendi (dalam Suryanti, 2016) siswa akan mampu mengikuti pelajaran matematika ditingkat selanjutnya apabila siswa mampu menguasai dengan baik konsep materi matematika di tingkat yang lebih rendah. Indikator pemahaman konsep dapat digunakan untuk mengukur pemahaman konsep siswa. Indikator pemahaman konsep menurut Kesumawati (dalam Zulbaili, 2016) yaitu sebagai berikut: (1) mengklasifikasikan objek menurut sifat-sifat tertentu, (2) menggunakan serta memilih prosedur atau operasi tertentu, (3) mengaplikasikan konsep atau algoritma pada pemecahan masalah.

Topik kubus dan balok diajarkan pada siswa dikelas VIII SMP. Topik tersebut membahas tentang luas permukaan dan volume dari kubus dan balok. Siswa mulai dikenalkan tentang kubus dan balok saat menempuh sekolah dasar selanjutnya diperdalam pada jenjang SMP. Materi kubus dan balok merupakan salah satu materi yang harus dikuasai oleh siswa karena memiliki peran penting dalam ilmu matematika yang dapat digunakan dalam kehidupan sehari-hari (Sugiyarti dalam Zulbaili, 2016). Oleh karena itu, pemahaman konsep siswa pada materi kubus dan balok perlu ditekankan sejak awal sebagai bekal awal untuk kemampuan matematika dalam memecahkan masalah matematika.

Berdasarkan wawancara dengan salah satu guru matematika SMP Negeri 23 Malang pada tanggal 21 januari 2019 terdapat beberapa masalah seperti siswa tidak mengingat konsep yang diajarkan ketika diberikan soal, siswa kesulitan membedakan rumus dari luas permukaan dan volume dari kubus dan balok, siswa kurang memahami soal yang diberikan guru khususnya pada soal cerita. Hasil tes pratindakan siswa di kelas VIII-4 SMP Negeri 23 Malang dengan materi bangun datar yaitu persegi dan persegi panjang masih rendah dengan persentase ketuntasan $13,33 \%$ dimana dari 30 siswa hanya 4 siswa yang mencapai ketuntasan. Sebagian besar siswa mengosongkan jawabannya dan jawaban siswa kurang tepat. Siswa belum bisa menyatakan ulang konsep dari persegi dan persegi panjang yaitu siswa tidak dapat menujukkan makna dari luas persegi dan persegi panjang. Selain itu, siswa belum bisa memilih prosedur untuk menyelesaikan soal dengan langkah-langkah yang lengkap dan tepat serta belum bisa menerapkan konsep untuk menyelesaikan soal. Konsep bangun datar merupakan konsep awal atau prasyarat untuk mempelajari materi selanjutnya yaitu bangun ruang sisi datar. Apabila topik persegi dan persegi panjang belum dipahami dengan baik maka akan sulit bagi siswa untuk memahami materi selanjutnya yaitu kubus dan balok.

Berdasarkan observasi kelas yang dilakukan oleh peneliti pada tanggal 22 Januari 2019 di kelas VIII-4 SMP Negeri 23 Malang diperoleh bahwa pembelajaran matematika di kelas masih berpusat pada guru. Tahapan pembelajaran yang dilakukan dikelas yaitu guru memberikan penjelasan terkait topik yang diajarkan, siswa mendengarkan dan mencatat apa yang ditulis guru, guru memberi contoh soal dan selanjutnya guru memberikan latihan soal kepada siswa. Berdasarkan pengamatan peneliti di kelas siswa cenderung pasif, terdapat 
beberapa siswa yang mengobrol di luar topik dengan teman sebangkunya, suasana kelas cukup ramai dan siswa sulit diatur sehingga guru memberikan teguran.

Siswa kesulitan dalam memahami topik yang diajarkan salah satunya disebabkan pembelajaran di kelas masih berpusat pada guru. Hal tersebut sesuai dengan yang dikemukakan Rosidah (2016) bahwa Pembelajaran matematika disekolah masih berpusat pada guru. Guru masih mendominasi dalam pembelajaran dan kurang melibatkan siswa secara aktif untuk mengkontruksi ide atau pemikirannya dalam pembelajaran. Pembelajaran yang berpusat pada guru (teacher centered) perlu di ubah menjadi pembelajaran yang berpusat pada siswa (student centered).

Salah satu alternatif metode pembelajaran yang diharapkan dapat mengatasi permasalahan tersebut adalah metode pembelajaran penemuan terbimbing. Metode penemuan terbimbing adalah proses memahami konsep dan mengaitkan dengan pengetahuan yang dimiliki sebelumnya oleh siswa secara tidak lepas dan bebas, tetapi masih berada dalam pengamatan dan bimbingan guru sehingga proses pembelajaran dapat terkendali dan terarah. Menurut Yuliani K (2015), metode penemuan terbimbing adalah metode pembelajaran dengan bimbingan dan arahan dari guru yang menyajikan masalah atau pertanyaan yang membuat siswa berfikir, mengamati, membuat hipotesis atau dugaan, menjelaskan dan menganalisis dalam menemukan pengetahuan. Ketika guru menggunakan metode penemuan terbimbing guru memberikan contoh-contoh, membantu siswa untuk menemukan pola dari contoh yang diberikan, kemudian siswa memberikan kesimpulan ketika siswa sudah mampu mendeskripsikan gagasan yang diajarkan oleh guru (Clark dalam Miftahul, 2016). Siswa mendapatkan pengalaman belajar melalui kegiatan mandiri maupun kelompok dalam memahami materi yang diajarkan dengan bantuan guru jika siswa mengalami kesulitan. Melalui metode pembelajaran penemuan terbimbing diharapkan siswa dapat menemukan dan memahami konsep dari topik yang diajarkan.

Berdasarkan uraian diatas, peneliti berharap metode pembelajaran penemuan terbimbing berguna dalam meningkatkan pemahaman konsep kubus dan balok siswa karena didukung oleh penelitian sebelumnya yang dilakukan oleh Didit Nantara (2016) dan Evi Nur Asiyah (2017). Oleh karena itu, tujuan penelitian ini adalah untuk mendeskripsikan proses penerapan metode pembelajaran penemuan terbimbing yang dapat meningkatkan pemahaman konsep kubus dan balok siswa kelas VIII-4 SMP Negeri 23 Malang.

\section{Metode}

Pada penelitian ini peneliti menggunakan pendekatan kualitatif dengan tujuan memperbaiki proses kegiatan pembelajaran yang dilaksanakan oleh guru di kelas. Pendekatan kualitatif mendeskripsikan penerapan metode pembelajaran penemuan terbimbing dalam memahamkan konsep siswa. Sedangkan jenis penelitian yang digunakan pada penelitian ini adalah penelitian tindakan kelas (PTK). Peneliti bertindak sebagai perencana tindakan, pelaksana tindakan, pengumpul data, pengamat kegiatan siswa, penganalisis data, penyusun laporan, dan pelapor hasil penelitian. Penelitian ini dilaksanakan di SMP Negeri 23 Malang pada semester genap tahun ajaran 2018/2019. Subjek penelitian ini adalah siswa kelas VIII-4 SMP Negeri 23 Malang yang terdiri dari 30 siswa diantaranya 21 siswa laki-laki dan 9 siswa perempuan. Data yang dikumpulkan peneliti adalah data mengenai seluruh proses kegiatan selama penelitian. Teknik pengumpulan data yang 
digunakan adalah tes akhir siklus, hasil observasi, dan catatan lapangan. Data yang dianalisis adalah tes pemahaman konsep siswa dan hasil observasi aktivitas guru dan siswa selama proses pembelajaran berlangsung. Data-data yang diperoleh kemudian dianalisis dengan menggunakan teknik analisis sebagai berikut:

\subsection{Data Hasil Validasi}

Perangkat pembelajaran dan instrumen penelitian yang telah disusun kemudian diserahkan kepada validator untuk divalidasi. Selanjutnya dianalisis dengan cara mencari skor rata-rata. Skor rata-rata hasil validasi dihitung dengan rumus sebagai berikut

$$
X=\frac{\text { Total } \text { Skor hasil validasi setiap validator }}{\text { banyaknya indikator }}
$$

\section{Keterangan:}

$X$ : skor rata-rata hasil validasi

Berdasarkan hasil penelitian validator akan diperoleh kriteria kevalidan yang ditentukan sebagai berikut.

Tabel 1 kriteria kevalidan perangkat dan instrument penelitian

\begin{tabular}{c|l}
\hline Interval & \multicolumn{1}{c}{ Kategori } \\
\hline $\mathbf{4} \leq \boldsymbol{X}<\mathbf{5}$ & Sangat valid \\
\hline $\mathbf{3} \leq \boldsymbol{X}<\mathbf{4}$ & Valid \\
\hline $\mathbf{2} \leq \boldsymbol{X}<\mathbf{3}$ & Kurang valid \\
\hline $\mathbf{1} \leq \boldsymbol{X}<\mathbf{2}$ & Tidak valid
\end{tabular}

(Diadopsi dari Arikunto)

\subsection{Data Hasil Observasi}

Data hasil observasi guru dan siswa diperoleh dari lembar observasi aktivitas guru dan siswa selama pembelajaran berlangsung. Persentase skor rata-rata hasil observasi aktivitas guru dan siswa dihitung menggunakan rumus berikut

$$
\mathrm{PR}=\frac{\text { jumlah skor yang diperoleh hasil observasi }}{\text { jumlah skor maksimal }} \times 100 \%
$$

Keterangan:

PR : persentase skor rata-rata hasil observasi

Data aktivitas siswa dan guru ditentukan dengan kriteria sebagai berikut.

Tabel 2 Kriteria Aktivitas Siswa dan Guru

\begin{tabular}{cl}
\hline \multicolumn{1}{l}{ Interval } & Kategori \\
\hline $\mathbf{8 5} \%<\mathbf{P R} \leq \mathbf{1 0 0} \%$ & Sangat baik \\
\hline $\mathbf{7 5} \%<\mathbf{P R} \leq \mathbf{8 5} \%$ & Baik \\
\hline $\mathbf{5 0} \%<\mathbf{P R} \leq \mathbf{7 5} \%$ & Cukup \\
\hline $\mathbf{0} \% \leq \mathbf{P R} \leq \mathbf{5 0} \%$ & Sangat Kurang \\
\hline (diadopsi dari Arikunto dengan modifikasi) &
\end{tabular}




\subsection{Data Hasil Tes}

Data hasil tes dapat diketahui dengan menghitung nilai hasil tes dari tes akhir siklus. Siswa dikatakan tuntas apabila nilai individu sudah mencapai KKM atau lebih yaitu $\geq 68$. Skor siswa pada setiap soal dihitung dengan menggunakan rumus yang ditentukan. Data hasil tes siswa dihitung menggunakan rumus berikut:

$$
\text { skor siswa }=\frac{\text { skor yang diperoleh }}{\text { skor maksimal }} \times 100
$$

Data hasil tes klasikal siswa dihitung menggunakan rumus berikut:

$$
\text { persentase } \text { klasikal }=\frac{\text { jumlah siswa yang tuntas }}{\text { jumlah siswa }} \times 100 \%
$$

Kriteria persentase klasikal siswa adalah $75 \%$

\section{Hasil dan Pembahasan}

\subsection{Hasil}

Penelitian tindakan kelas ini terdiri dari perencanaan tindakan, pelaksanaan tindakan, observasi, dan refleksi. Pada siklus 1 dan siklus 2 masing-masing terdiri dari 3 pertemuan dengan setiap pertemuan dilaksanakan dalam $2 \times 40$ menit. Penelitian ini dimulai 28 Januari 2019 dan selesai pada tanggal 18 Februari 2019. Selama pelaksanaan penelitian terdapat hasil yang diperoleh seperti yang penulis paparkan berikut.

\subsubsection{Hasil observasi aktivitas siswa dan guru (siklus 1 dan siklus 2)}

Tabel 3 hasil observasi aktivitas siswa dan guru

\begin{tabular}{l|l|l}
\hline Siklus & $\begin{array}{l}\text { Persentase Rata-rata } \\
\text { Kegiatan Guru }\end{array}$ & $\begin{array}{l}\text { Persentase Rata-rata } \\
\text { Kegiatan Siswa }\end{array}$ \\
\hline $\mathbf{1}$ & $84,21 \%$ & $79,5 \%$ \\
\hline $\mathbf{2}$ & $89,58 \%$ & $88,16 \%$
\end{tabular}

Berdasarkan tabel di atas, hasil observasi aktivitas siswa dalam belajar siklus 1 diperoleh persentase sebesar 79,5\% mengalami peningkatan pada siklus 2 dengan persentase 88,16 \% dengan kategori keberhasilan aktivitas siswa siklus 1 termasuk dalam kategori baik dan pada siklus 2 termasuk dalam kategori sangat baik. Hasil observasi aktivitas guru juga mengalami peningkatan dari siklus 1 ke siklus 2 dengan persentase 84,21\% menjadi 89,58\% dengan kategori keberhasilan termasuk dalam kategori sangat baik.

\subsubsection{Hasil tes akhir siklus}

Tabel 4 Hasil Tes Akhir Siklus 1

\begin{tabular}{lllc}
\hline Ketuntasan & Jumlah Siswa & Jumlah seluruh siswa & Persentase \\
\hline Tuntas & 20 & 30 & $66,67 \%$ \\
\hline Tidak Tuntas & 10 & 30 & $33,33 \%$ \\
\hline
\end{tabular}


Berdasarkan tabel diatas, dari 30 siswa kelas VIII-4 SMP Negeri 23 Malang diperoleh 20 siswa atau $66,67 \%$ siswa yang tuntas belajar sedangkan 10 siswa atau $33,33 \%$ tidak tuntas.

Tabel 5 Hasil Tes Akhir Siklus 2

\begin{tabular}{llll}
\hline Ketuntasan & Jumlah Siswa & Jumlah seluruh siswa & Persentase \\
\hline Tuntas & 26 & 30 & $86,6 \%$ \\
\hline Tidak Tuntas & 4 & 30 & $13,33 \%$ \\
\hline
\end{tabular}

Berdasarkan tabel diatas, hasil tes akhir siklus 2 siswa kelas VIII-4 SMP Negeri 23 Malang sudah mencapai ketuntasan sesuai kriteria yang ditentukan. Terdapat 26 siswa atau 86,6 \% siswa sudah mencapai ketuntasan dan 4 siswa atau 13,33\% belum mencapai ketuntasan. Hal tersebut berarti terjadi peningkatan pemahaman konsep kubus dan balok siswa dari siklus 1 ke siklus 2 .

\subsection{Pembahasan}

Berdasarkan hasil penelitian tahapan penerapan metode pembelajaran penemuan terbimbing yang dapat meningkatkan pemahaman konsep adalah sebagai berikut:

\subsubsection{Tahap Penyajian masalah}

Tahap penyajian masalah dilakukan pada siklus 1 dan siklus 2, tetapi pada siklus 1 hanya beberapa siswa yang aktif saja dalam mengemukakan pendapatnya, siswa lainnya mengobrol di luar topik dan siswa yang pasif cenderung diam. Sedangkan pada siklus 2 siswa yang terlihat ramai dan pasif sudah mulai mengemukakan pendapatnya karena guru menujuk siswa tersebut untuk membacakan permasalahan yang diberikan kemudian menyampaikan informasi apa saja yang diketahui dan ditanyakan pada permasalahan.

\subsubsection{Tahap mengumpulkan data}

Pada tahap mengumpulkan data, guru meminta siswa berdiskusi kelompok untuk menjawab pertanyaan yang ada pada LKS dengan mengaitkan pengetahuan yang sudah dimiliki siswa agar dapat mengarah pada konsep yang akan dicari. Tahap mengumpulkan data dilakukan pada siklus 1 dan siklus 2. Pada siklus 1, sebagian besar kelompok masih memerlukan banyak bimbingan dari guru. Siswa lebih banyak bertanya sebelum membaca langkah-langkah pertanyaan yang ada pada LKS. Pada siklus 2 siswa sudah mampu mengumpulkan data dan menjawab pertanyaan yang diberikan karena guru mengingatkan siswa untuk membaca terlebih dahulu pertanyaan yang ada pada LKS.

\subsubsection{Tahap membuat Hipotesis}

Pada tahap membuat hipotesis, guru meminta setiap kelompok untuk berdiskusi dalam membuat dugaan sementara dari kegiatan yang telah dilakukan selanjutnya mempresentasikan dan guru memberi penegasan atas dugaan siswa. Tahap membuat hipotesis dilakukan pada siklus 1 dan siklus 2, tetapi pada siklus 1 siswa masih kesulitan dalam membuat hipotesis dan masih banyak siswa yang ramai. Pada siklus 2, setiap kelompok sudah mampu membuat dugaan sementara secara mandiri dikarenakan siswa 
sudah mulai terbiasa dan mengerti dalam membuat hipotesis. Pada siklus 2, guru lebih tegas dan meminta siswa yang terlihat ramai untuk mempresentasikan hasil dugaannya

\subsubsection{Tahap membuat kesimpulan}

Pada tahap membuat kesimpulan, guru meminta setiap kelompok menuliskan kesimpulan dari seluruh kegiatan yang telah dilakukan. Tahap membuat kesimpulan dilakukan pada siklus 1 dan siklus 2. Pada siklus 1 terdapat beberapa siswa yang tidak menuliskan kesimpulan pada LKS. Pada siklus 2 setiap kelompok sudah menuliskan kesimpulan pada LKS karena guru mengecek jawaban siswa dengan mengelilingi setiap kelompok, memantau proses diskusi siswa dan memberikan bimbingan apabila siswa merasa kesulitan.

\subsubsection{Tahap evaluasi dan latihan soal}

Pada tahap evaluasi dan latihan soal, guru meminta siswa untuk menyelesaikan masalah yang ada pada tahap penyajian masalah dan meminta siswa untuk mengerjakan latihan soal. Pada tahap ini siswa diharapkan dapat menerapkan konsep yang diperoleh untuk menyelesaikan masalah. Tahap evaluasi dan latihan soal dilakukan pada siklus 1 dan siklus 2, tetapi pada siklus 1 banyak siswa yang belum bisa menyelesaikan soal dengan lengkap dan siswa lupa menuliskan yang diketahui dan yang ditanyakan dari permasalahan. Selain itu banyak siswa yang belum memahami maksud dari soal sehingga kesulitan dalam menyelesaikan soal. Pada siklus 2, siswa sudah mulai terbiasa membaca kembali soal dan memahami soal telebih dahulu karena guru mengingatkan siswa agar memahami masalah terlebih dahulu kemudian menuliskan apa yang diketahui dan ditanyakan pada masalah selanjutnya menyelesaikan masalah dengan langkah-langkah penyelesaian yang lengkap dan tepat.

Hasil Penelitian menujukkan bahwa hasil observasi aktivitas guru dan siswa dalam pembelajaran dengan menerapkan metode pembelajaran penemuan terbimbing yang dapat meningkatkan pemahaman konsep kubus dan balok termasuk dalam kategori sangat baik untuk siklus 2. Selain itu, hasil penelitian menujukkan terdapat peningkatan pemahaman konsep kubus dan balok setelah diterapkan metode pembelajaran penemuan terbimbing. Peningkatan tersebut terlihat dari hasil tes siswa siklus 1 dan siklus 2. Hasil observasi aktivitas siswa dan guru serta hasil tes siswa siklus 1 dan 2 dapat di lihat pada tabel 5.1 berikut.

Tabel 6 Hasil Tes Akhir, Persentase Rata-rata Kegiatan guru dan Siswa Siklus 1 dan siklus 2

\begin{tabular}{cccll}
\hline Siklus & $\begin{array}{l}\text { Persentase } \\
\text { Ketuntasan }\end{array}$ & $\begin{array}{l}\text { Nilai Rata- } \\
\text { rata Kelas }\end{array}$ & $\begin{array}{l}\text { Persentase } \\
\text { Rata-rata } \\
\text { Kegiatan Guru }\end{array}$ & $\begin{array}{l}\text { Persentase } \\
\text { Rata-rata } \\
\text { Kegiatan Siswa }\end{array}$ \\
\hline $\mathbf{1}$ & $66,67 \%$ & 68,2 & $84,21 \%$ & $79,5 \%$ \\
\hline $\mathbf{2}$ & $86,6 \%$ & 80,13 & $89,58 \%$ & $88,16 \%$ \\
\hline
\end{tabular}




\section{Simpulan}

\subsection{Kesimpulan}

Berdasarkan pembahasan hasil penelitian disusun simpulan tentang proses pembelajaran dengan menerapkan metode penemuan terbimbing yang dapat meningkatkan pemahaman konsep siswa pada materi kubus dan balok di kelas VIII-4 SMP Negeri 23 Malang sebagai berikut.

\subsubsection{Penyajian masalah}

Pada tahap penyajian masalah, guru meminta salah satu siswa untuk membaca permasalahan yang diberikan serta menujuk siswa yang terlihat pasif dan ramai untuk menuliskan apa saja informasi yang dapat diperoleh dari permasalahan dengan menuliskan apa yang diketahui dan ditanya dari masalah.

\subsubsection{Mengumpulkan data}

Pada tahap mengumpulkan data siswa diminta untuk membaca langkah-langkah pertanyaan yang ada pada LKS dan mendiskusikannya dengan teman satu kelompok sebelum bertanya pada guru. Guru memberikan bimbingan seperlunya kepada siswa hal ini bertujuan agar siswa tidak berpacu pada penjelasan guru.

\subsubsection{Tahap membuat hipotesis}

Pada tahap membuat hipotesis, siswa diminta untuk membuat dugaan dari kegiatan yang telah dilakukan sebelumnya yaitu pada tahap mengumpulkan data. Pada tahap ini siswa mempresentasikan hasil diskusinya di depan kelas dan guru memberikan penegasan terhadap dugaan siswa apakah sudah benar atau belum. Hal tersebut penting dilakukan karena untuk menyakinkan hasil dugaan siswa sehingga menuju arah yang hendak dicapai.

\subsubsection{Tahap membuat kesimpulan}

Pada tahap membuat kesimpulan, guru mengelilingi setiap kelompok untuk melihat hasil kesimpulan yang telah dibuat serta menujuk salah satu siswa dalam setiap kelompok untuk menyampaikan hasil kesimpulannya. Kesimpulan yang dibuat siswa berdasarkan dari seluruh kegiatan yang telah dilakukan sebelumnya.

\subsubsection{Tahap evaluasi atau latihan soal}

Pada tahap evaluasi dan latihan soal, guru meminta siswa untuk menyelesaikan masalah yang ada pada tahap penyajian masalah dan selanjutnya siswa mengerjakan latihan soal.

\subsection{Saran}

Berdasarkan kesimpulan yang telah dipaparkan peneliti di atas, peneliti memberikan saran dalam penerapan metode pembelajaran penemuan terbimbing sebagai berikut:

4.2.1. Berdasarkan hasil penelitian, melalui metode pembelajaran penemuan terbimbing siswa mendapatkan pengalaman belajar dimana siswa dapat mengkonstruk pemikirannya 
secara mandiri, sehingga metode penemuan terbimbing dapat diterapkan oleh guru dalam pembelajaran matematika.

4.2.2. Ketika menerapkan metode penemuan terbimbing, guru sebaiknya memberikan bantuan seperlunya agar siswa dilatih untuk berpikir secara mandiri, dan tidak berpacu pada penjelesan guru

4.2.3. Penerapan metode pembelajaran penemuan terbimbing membutuhkan waktu yang cukup lama, agar siswa lebih memahami topik yang diajarkan sebaiknya topik yang di sampaikan pada setiap pertemuan tidak begitu banyak.

\section{Daftar Rujukan}

Akmil, A. R. Armiati, \& Rizal, Y.(2012). Implementasi CTL dalam meningkatkan pemahaman konsep matematika siswa. Jurnal Pendidikan Matematika, 1(1), 24-29.

Alfiah, F., Lathiful, A. (2016, Agustus 13). Penerapan problem based-learning untuk meningkatkan pemahaman konsep persamaan dan fungsi kuadrat siswa kelas X BB-2 SMK Negeri 5 Malang. Makalah disajikan dalam Seminar Nasional Matematika dan Pembelajarannya, Jurusan Matematika FMIPA UM, Malang.

Arikunto, S. (2009). Dasar-dasar evalauasi pendidikan. Jakarta: Rineka Cipta.

Arikunto, S. (2014). Prosedur penelitian suatu pendekatan praktik. Jakarta: Rineka Cipta.

Banowati, H. (2015). Upaya Meningkatkan Pemahaman Konsep Matematika Melalui Pendekatan Contextual Teaching And Learning (CTL) Pada Siswa Kelas VII B SMP Negeri 4 Banguntapan. Universitas PGRI Yogyakarta.

Miftahul, F.A., Sri, Mulyati., Akbar, S. (2016, Agustus 13). Pembelajaran teorema pythagoras dengan metode penemuan terbimbing: Implementasi James Abram Garfield. Makalah disajikan dalam Seminar Nasional Matematika dan Pembelajarannya, Jurusan Matematika FMIPA UM, Malang.

Rosidah, Kholifatur, dkk. (2016, Agustus 13). Penggunaan software geogebra dalam membantu siswa memahami konsep persamaan garis lurus. Makalah disajikan dalam Seminar Nasional Matematika dan Pembelajarannya, Jurusan Matematika FMIPA UM, Malang.

Subanji, S. (2013). Pembelajaran matematika kreatif dan inovatif. Malang. Universitas Negeri Malang.

Suryanti, L., Muhsetyo, G., \& Susanto, H. (2016). Pemahaman konsep siswa pada unsur-unsur bangun ruang sisi lengkung. Matematika dan Pembelajarannya, 506-5012.

Yuliani, K., \& Saragih, S. (2015). The development of learning devices based guided discovery model to improve understanding concept and critical thinking mathematically ability of students at Islamic Junior High School of Medan. Journal of education and practice, 6(24), 116-128.

Zulbaili. (2016, Agustus 13). Pemahaman konsep kubus dan balok siswa SMP. Makalah disajikan dalam Seminar Nasional Matematika dan Pembelajarannya, Jurusan Matematika FMIPA UM, Malang. 